\title{
Enriched plum filling for the confectionery
}

\author{
*Alibekov, R.S., Kenzhibayeva, G.S., Utebaeva, A.A., Urazbayeva, K.A., Tursynbay, L.M. \\ and Kulanova, D.A. \\ M.Auezov'South-Kazakhstan State University, 160000 Tauke Khan avenue, 5 Shymkent, Republic of \\ Kazakhstan.
}

\begin{abstract}
Article history: July 2020

December 2020

\section{Keywords:}

Antioxidants,

Confectionery,

Filling,

Plum,

Minerals,

Vitamins
\end{abstract}

Received: 11 April 2020

Received in revised form: 20

Accepted: 22 July 2020

Available Online: 27

DOI:

https://doi.org/10.26656/fr.2017.4(S6).014

\begin{abstract}
The useful nutritional value of plum is related to the most quantity of vitamins like Vitamin A - beta carotene, Thiamin $\left(\mathrm{B}_{1}\right)$, Riboflavin $\left(\mathrm{B}_{2}\right)$, Niacin $\left(\mathrm{B}_{3}\right)$, Pantothenic acid $\left(\mathrm{B}_{5}\right)$, Vitamin $\mathrm{B}_{6}$, Folate $\left(\mathrm{B}_{9}\right)$, Vitamin $\mathrm{C}$, Vitamin $\mathrm{E}$, Vitamin $\mathrm{K}$; and minerals: $\mathrm{Ca}, \mathrm{Fe}$, $\mathrm{Mg}, \mathrm{Mn}, \mathrm{Ph}, \mathrm{K}, \mathrm{Na}$ and other. Plum is available in the receipts of various confectioneries: sweets, caramels, creams, jellies, cookies and others. The objective of the presented study was to develop a new of natural origin with antioxidants capacity - plum filling for the confectionery. Sensory assessment of the researched samples was provided by "JustAbout-Right-Test" questionnaire for the following main characteristics: taste, colour, odour, texture or consistence and acceptance of the product. Organoleptic and physicochemical characteristics were analyzed in accordance with the GOST 32741-2014 (Interstate standard) requirements. The content of mineral substances was determined by the method of Mass-spectrometry with inductively coupled plasma (ICP-MS) and using a Scanning Electron Microscope (SEM). As a result of the «Just-About-Right-Test» most of the respondents selected a plum filling sample with gelatin and lemon. This statement was confirmed by organoleptic and physicochemical characteristics. The mass-spectrometry database verified availability of essential macro- and microelements: sodium, magnesium, phosphorus, sulphur, potassium, calcium, iron and other. The proposed plum filling has wide range applications, as inside and outside for the covering of confectionery, thereby organoleptic properties and nutritional value of final product could be enriched.
\end{abstract}

\section{Introduction}

By recommending the using of a particular food product, it is necessary to take into account its antioxidant activity. This is an extremely important value that indicates the presence of substances and neutralizes the excess of free radicals and interrupts the chain of oxidative reactions that damage the cells and tissues of the human body. An excess of free radicals is formed as a result of the unbalanced diet, malnutrition or obesity, poor ecology, daily stresses, smoking et al. Reducing the antioxidant status of the human organism can reduce immunity, lead to the emergence and development of many pathological processes, in particular diseases of the gastrointestinal tract, metabolism and its related internal organs (Alibekov et al., 2018). The main sources of natural antioxidants for humans are raw fruits and vegetables (Alibekov, Gabrilyants, Tursunbay et al., 2019).
The nutritional value of fresh fruit is highly important for modern food manufacturers owing to the constantly growing interest in the "health-providing" properties to some food products based on the observation and scientifically proved postulates that their regular consumption beneficially influences human health by strengthening the body's defense against several chronic diseases (Peri, 2006).

The usage of local resources of non-traditional raw materials is the most promising and effective in the technological and economical aspects. The unconventional raw materials are a valuable source of healthy nutrients (Tkachenko, 2016).

Plums have low-calorie content and relatively high nutritive value. They contain carbohydrates, first of all sucrose, glucose and fructose, organic acids, e.g. citric and malic acids, fibre (pectins), tannins, aromatic substances and enzymes. These substances determine the 
nutritive value and taste of plums (Ertekina et al. 2006) (Walkowiak-Tomczak et al., 2008).

Due to its availability, cheapness and nutritional value, plum is widely used in the food industry. Plum is applied in the production of such well-known food products as candied fruit, juices, fruit drinks, jams, preserves, jams, marmalades, etc. Plum is used in the production of flour confectionery: rolls, muffins, cookies, biscuits and others. Also, in the form of additional raw materials, plum is available in the receipts of sugar-containing confectionery: various sweets, caramels, creams, jellies and others. The useful nutritional value of plum is related to the most quantity of vitamins like Vitamin $\mathrm{A}$ - beta carotene, Thiamin $\left(\mathrm{B}_{1}\right)$, Riboflavin $\left(\mathrm{B}_{2}\right)$, Niacin $\left(\mathrm{B}_{3}\right)$, Pantothenic acid $\left(\mathrm{B}_{5}\right)$, Vitamin $\mathrm{B}_{6}$, Folate $\left(\mathrm{B}_{9}\right)$, Vitamin $\mathrm{C}$, Vitamin E, Vitamin $\mathrm{K}$; and minerals: $\mathrm{Ca}, \mathrm{Fe}, \mathrm{Mg}, \mathrm{Mn}, \mathrm{Ph}, \mathrm{K}, \mathrm{Na}$ and other. Vitamins C, E and beta carotene (a form of vitamin A), as well the flavonoids' representative subclass anthocyanidins are presented in plum. All these compounds have antioxidant properties and maybe as a protective source against cardiovascular disease, premature ageing and may contribute to the protective effects in the antioxidant-rich diets (Alibekov, Gabrilyants, Tursunbay et al., 2019).

Moreover, as a secondary raw material, the processed plum kernel shells can be used for the obtaining activated carbons in practical application as adsorbents for adsorption from solutions of various large -scale productions of organic compounds, for the extraction and concentration of valuable components, purification of natural and industrial waters (Satayev et al., 2015).

In our early studies, we researched possibilities in the application of the biological active substances and antioxidants of natural plant origin for the enrichment of the functional features and nutritional values in the various food technologies, such as: quince powder in bakery (Alexeeva et al., 2018), apple pectin in tomato juice (Alibekov and Utebaeva, 2014), plum filling in caramel (Alimova et al., 2014), Circassian walnut and lemon juice in eastern sweet (Alibekov et al., 2016), pumpkin puree and carrot juice in marmalade (Kassymova et al., 2012), carrot and holy thistle (Silybum) powder in macaroni (Alibekov et al., 2017), polyphyto-component in dairy (Shingisov et al., 2017) and meat products (Shingisov et al., 2016) and other. So, as polyphyto-component for the food products following raw materials were used: the hawthorn fruits, sage flowers, thyme, oregano, basil leaves and clove buds (Shingisov et al., 2016).

Furthermore, as well-known a lot of works that are related for the supplementations of plant origin additives to the confectionary. For instance, pumpkin powder in sponge cake has raised level of $\beta$-carotene and protein (Hosseini Ghaboos et al., 2018), melon in jam is important source of antioxidants (Benmeziane et al., 2018), mango in jelly is a good alternative for increasing the content of phytochemical compounds (Gurak et al., 2018), pumpkin puree has the potential to be used as butter replacer in the formulation of muffin (Arifin et al., 2019), physicochemical and sensory properties of baked cake 'kuih bakar' can be maintained by using fresh soy milk as a substitution of the traditional coconut milk (Maimanah-Faizah et al., 2020), belimbi fruit jam prepared from maltitol and belimbi fruit jams from sucrose may be labeled as 'jam' product as well as 'reduced-calorie jam' (Ho et al., 2020) and other.

Confectionery, a term with blurred edges, but generally indicating a delicacy which is sweet, is usually eaten with the fingers and keeps for some time. The world of "confection" is related to medieval Latin confecta and the English word confit, with meaning associated with the preparation of a mixture, and preservation in sugar (Davidson and Jaine, 2014).

In general, confectionery is divided into two broad and somewhat overlapping categories: bakers' (or flour) confections and sugar confections (International Food Information Service, 2009).

Biscuits and cookies are small, sweetened, cerealbased, baked products. They are broadly characterized by dough properties and then further classified by the process used to form and place them on the oven band (Miller, 2016).

It is known that a composition of filling heat-stable includes raw materials from fruits and vegetables, sugar, starch, gelatin and citric acid (Popel et al., 2018).

Confectionery fillings are products such as fondants or cremes which may contain nuts, flavorings or other ingredients, and are used to fill sugar confectionery or bakery products (International Food Information Service, 2009).

By taking into account the above-mentioned data, the purpose of the presented study was to develop a new natural origin with antioxidants capacity - plum filling for the confectionery.

\section{Materials and methods}

\subsection{Raw materials}

Basically, standard generally known and modified research methods of raw materials and final products were used. 
Raw materials include raw plum according to the GOST 21920-2015 (Federal Agency for Technical Regulation and Metrology, 2015), lemon according to the GOST 34307-2017 (Federal Agency for Technical Regulation and Metrology, 2017), gelatin according to the GOST 11293-89 (State Agroindustrial Committee, 1989) and sugar in accordance with the GOST 332222015 (Federal Agency for Technical Regulation and Metrology, 2015).

\subsection{Sample preparation}

For the obtaining of the plum filling samples, basically in the composition a mixture of treated raw plum without seeds, red beet puree and sugar was used. Then, $3-5 \%$ of gelatine and lemon in variations were applied. Each sample was prepared separately. In generally, raw materials are boiled in the boiling apparatus, till a soluble solids content of $64.0 \pm 2.0 \%$ and cooled to a temperature of $80^{\circ} \mathrm{C}$, then transferred for the packaging.

Following four types of plum filling samples were selected for the research: No. 1 - control or processed plum mixture component without any additives; No. 2 plum mixture component with gelatine; No. 3 - plum mixture component with lemon; and No. 4 - plum mixture component with gelatine and lemon.

\subsection{Sensory assessment}

Sensory assessment was provided by "Just-AboutRight-Test" (Alibekov et al., 2016). "Just-About-RightTest" method is used in the sensory analysis for following: establishing whether there is a preference between the evaluated samples; determining which of the samples may be more preferable between consumers and elimination of deficiencies, if they exist in the recipe. This method allows to have more advanced results in the main categories, such as: taste, colour, odour, texture or consistence and acceptance of the product.

A total of twenty panellists conducted the sensory evaluation. Samples and questionnaire sheets were distributed to panellists. Panellists were instructed to taste the samples in a sequence and then evaluate the samples by selecting the scale in the questionnaire sheet with denotation as follows:

Here are 4 (four) different types of plum fillings. Please, taste them and indicate your opinion about the following characteristics:

Question 1. How do you feel about the lemon taste in the plum filling?

5) I would like it much more intensive

4) I would like it a bit more intensive

3) I like it. It's just right
2) I would like it a bit less intensive

1) I would like it much less intensive

Question 2. How do you like the colour of the plum filling?

5) I like it very much

4) I like it fairly well

3) I like it. It's just right

2) Dislike fairly well

1) Dislike very much

Question 3. How do you feel the odour of the plum filling?

5) I would like it much more intensive

4) I would like it a bit more intensive

3) I like it. It's just right

2) I would like it a bit less intensive

1) I would like it much less intensive

Question 4. How do you feel the texture or consistence of the plum filling?

5) It's far too thick

4) It's a bit too thick

3) I like it. It's just right

2) It's not thick enough

1) I would like it much more liquid

Question 5. How do you like the taste of the product?

5) I like it very much

4) I like it fairly well

3) I like it. It's just right

2) Dislike fairly well

1) Dislike very much

Question 6. How acceptable is the product?

5) I like it very much

4) I like it fairly well

3) I like it. It's just right

2) Dislike fairly well

1) Dislike very much

Data collected from the questionnaire sheets were analysed by statistical means.

\subsection{Organoleptic characteristics}

Organoleptic characteristics including: appearance and consistency, taste and smell, colour were analysed in accordance with the GOST 32741-2014.

\subsection{Physicochemical characteristics}

In the presented work, the physicochemical indicators of plum fillings: mass fraction of soluble solids, titratable acidity and mineral impurities were identified in accordance with the GOST 32741-2014 
2.6 Macro- and microelements contents in the plum fillings

The content of mineral substances in a plum filling was determined by the method of Mass-spectrometry with inductively coupled plasma (ICP-MS) and using a Scanning Electron Microscope (SEM). The method of mass-spectrometry with inductively coupled plasma (ICP -MS) allows defining a number of metals and several non-metals at concentrations up to $10^{-10} \%$, i.e. one particle of $10^{-12}$, with the atomic mass from 7 to 250 , i.e. from $\mathrm{Li}$ to $\mathrm{U}$ elements. It is able to determine the content of nanograms per liter to 10 to 100 milligrams per liter. The method is based on using of the inductive-connected plasma, as a source of ions and mass spectrometer for their separation and detection in an argon atmosphere. Unlike atomic absorption spectroscopy, defining only one element, ICP-MS can identify all elements simultaneously, which allows to considerably speed up the process of measurement (Thompson and Wolsh, 1988).

Scanning electron microscope (SEM) allows observing the subtle features of using micro analyzing of chemical composition, and the details of the structure of micro-objects on the atomic and molecular level. It can also to receive the image of object surface with a high (up to $0.4 \mathrm{~nm}$ ) spatial resolution, also information about the composition, structure and some other properties of the surface layers. SEM has a great depth of focus that allows observing the three-dimensional image of the structure with the possibility of its qualitative evaluation. Preparation of ash samples for the analysis of the chemical composition were performed according to the GOST 26929-94. The method of dry mineralization is based on full decomposition of organic substances by combustion of the sample in an electric stove at a controlled temperature of $450-500^{\circ} \mathrm{C}$ (Alibekov, Kaiypova, Urazbayeva et al., 2019).

The obtained ash samples were researched in the
M.Auezov' South-Kazakhstan State University laboratory by qualified specialists. The operation principle of the scanning electron microscope (SEM) is above mentioned.

\section{Results and discussion}

Organoleptic characteristics were analysed in accordance with the GOST 32741-2014 (Interstate standard) requirements (Table 1).

Basically, the "Appearance" for the first sample had a dense mass, easily smeared texture. For the second, third and fourth compositions this feature was a same: a dense mass, easily smeared consistency. Because it was related for the additives: lemon and gelatin, in variations.

The next indicator "Taste and smell" was a specific for the additives. So, for the first control sample was identified sour-sweet taste, characteristic to plum, no odor. The second sample with gelatin had sour-sweet taste, no odor. For the third sample with lemon was sensed pleasant, plumy, soursweet taste. The fourth sample with gelatin and lemon had well pleasant, plumy, sour-sweet taste and pleasant smell.

The "Consistency" characteristic was a same for all samples - jelly-like mass. It confirms that the general technological parameters in the obtaining for the four cases were accurate kept.

However, the "Colour" was related for the added ingredients. For instance, for the control sample - burgundy brown or specific for the plum colour. For the second sample with gelatin was deep burgundy. For the third sample with lemon was dark red, burgundy. Finally, the fourth sample with gelatin and lemon had pleasant burgundy brown tint.

Analysis of the results of the organoleptic evaluation of samples produced using gelatin and lemon testifies to the originality of the finished product. Taste, smell, colour, appearance and consistency fully meet the requirements for fillings.

Table 1. Organoleptic characteristics of plum fillings

\begin{tabular}{|c|c|c|c|c|c|}
\hline \multirow{2}{*}{ Attributes } & \multirow{2}{*}{ GOST 32741-2014 } & \multicolumn{4}{|c|}{ Plum filling samples } \\
\hline & & No. 1 & No. 2 & No. 3 & No. 4 \\
\hline Appearance & $\begin{array}{l}\text { Filling - a dense mass with a smearing or jelly } \\
\text { texture with evenly distributed fruits and / or } \\
\text { vegetables or with its parts or without them. } \\
\text { Candying is not allowed }\end{array}$ & $\begin{array}{l}\text { A dense mass, } \\
\text { easily smeared } \\
\text { texture }\end{array}$ & $\begin{array}{l}\text { A dense mass, } \\
\text { easily smeared } \\
\text { consistency }\end{array}$ & $\begin{array}{l}\text { A dense mass, } \\
\text { easily smeared } \\
\text { consistency }\end{array}$ & $\begin{array}{l}\text { A dense mass, } \\
\text { easily smeared } \\
\text { consistency }\end{array}$ \\
\hline $\begin{array}{c}\text { Taste and } \\
\text { smell }\end{array}$ & $\begin{array}{l}\text { Well-defined, with sour-sweet taste, characteristic of } \\
\text { the components from which the semi-finished } \\
\text { products are made. } \\
\text { Foreign taste and odor not allowed }\end{array}$ & $\begin{array}{l}\text { Sour-sweet taste, } \\
\text { characteristic to } \\
\text { plum, no odor }\end{array}$ & $\begin{array}{l}\text { Sour-sweet taste, } \\
\text { no odor }\end{array}$ & $\begin{array}{l}\text { Pleasant, plumy, } \\
\text { sour-sweet taste }\end{array}$ & $\begin{array}{l}\text { Pleasant, plumy, } \\
\text { sour-sweet taste } \\
\text { and pleasant } \\
\text { smell }\end{array}$ \\
\hline Consistency & $\begin{array}{l}\text { Jelly-like mass. For thermostable fillings - a dense } \\
\text { mass that does not spread when heated to a } \\
\text { temperature of } 170^{\circ} \mathrm{C}-220^{\circ} \mathrm{C}\end{array}$ & Jelly-like mass & Jelly-like mass & Jelly-like mass & Jelly-like mass \\
\hline Colour & $\begin{array}{l}\text { Intrinsic to heat-treated fruits and / or vegetables, from } \\
\text { which fillings are made. }\end{array}$ & $\begin{array}{l}\text { Burgundy } \\
\text { brown }\end{array}$ & Deep burgundy & $\begin{array}{l}\text { Dark red, } \\
\text { burgundy }\end{array}$ & $\begin{array}{l}\text { Pleasant, } \\
\text { burgundy brown }\end{array}$ \\
\hline
\end{tabular}




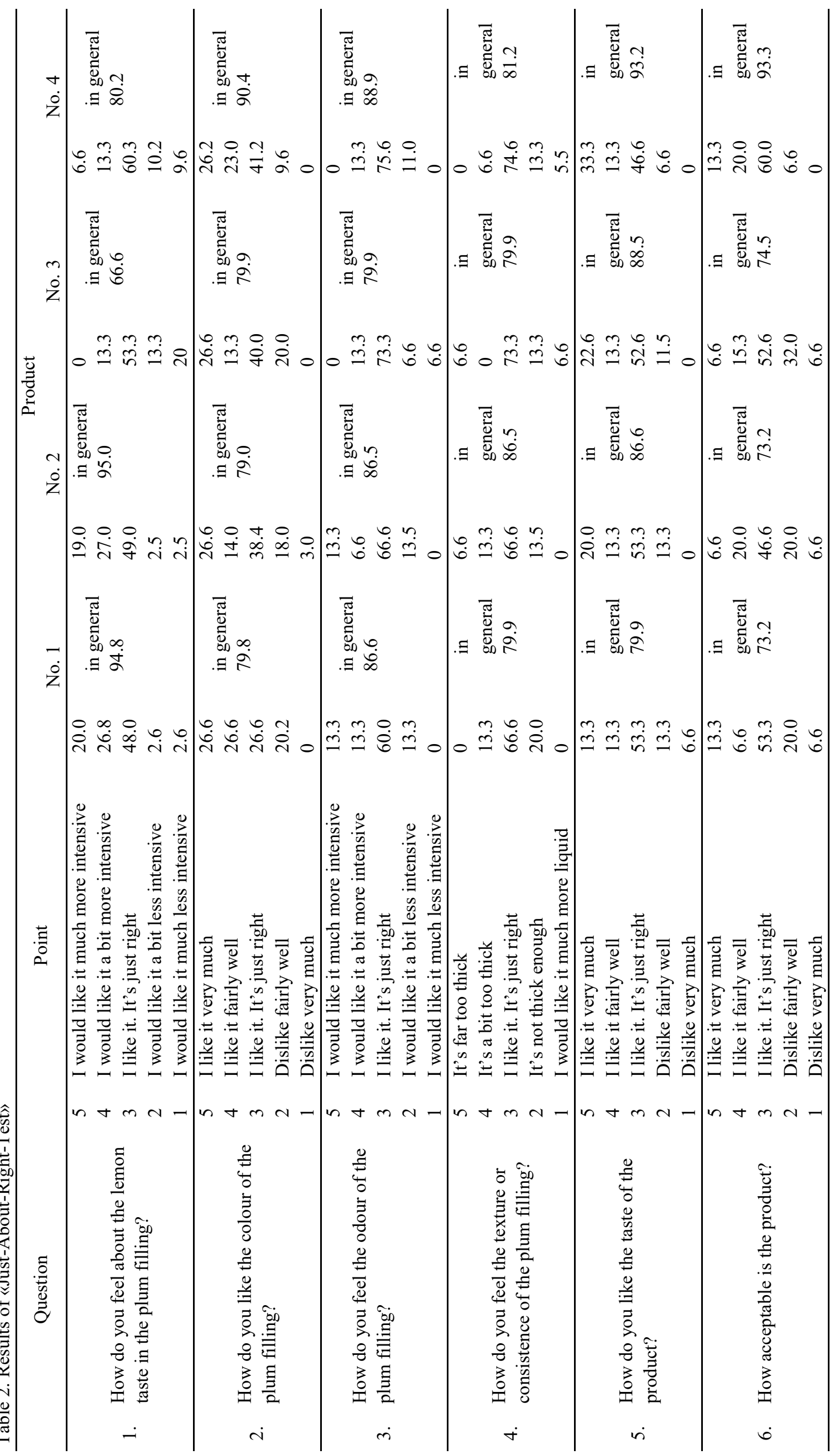


As well as «Just-About-Right-Test» was conducted to determine which of the samples may be more preferable between consumers (Table 2).

During «Just-About-Right-Test» of sensory analysis, 20 tasters were participated. All filled sheets were accepted and calculated by percentage per total opinions. As a result, their answers to questions and about their opinion, all 4 types of plum fillings are preferred in their own way. But, most tasters $80-90 \%$ appreciated with the plum filling No.4 with gelatin and lemon. The survey results are shown in Table 2 .

As a result of the sensory analysis, more than $80 \%$ of the questioned respondents selected sample No. 4: plum filling with gelatin and lemon.

As well a comparison of the physicochemical parameters of the plum fillings with and without gelatin and lemon was done (Table 3 ).

\subsection{Macro- and microelements contents in the plum fillings}

The compositions of macro- and microelements of the investigated plum fillings samples by using ICP-MS have the following data (Table 4, Figure 1).

Analysis of the ICP-MS data shows that two essential organic elements carbon and oxygen are presented in high volume for all samples: $18.64-25.88$ $(\mathrm{mg} / \mathrm{kg})$ and $41.20-42.65(\mathrm{mg} / \mathrm{kg})$ properly. These elements can be from the carbohydrate structure of the plum and lemon.

All plum fillings were found to contain sodium, magnesium, phosphorus, sulphur, potassium, calcium and iron. Moreover, a content of the potassium is in majority 24.99 - $32.32(\mathrm{mg} / \mathrm{kg})$. As known, potassium and sodium are systemic electrolytes and essential in the co-regulating of ATPase or Adenosine triphosphatase (Clausen et al., 2017).

Besides, mass fractions of the fourth sample that consists of plum mixture component with gelatine and lemon by magnesium, phosphorus, sulphur, calcium and iron have more values than other samples. This fact is associated with the increasing of the gelatine and lemon joint availability.

Two microelements are presented in the first sample

Table 3. Physicochemical indicators of plum fillings

\begin{tabular}{lccccc}
\hline \multicolumn{1}{c}{ Name of the indicator } & GOST 32741-2014 & \multicolumn{3}{c}{ Plum fillings } \\
\cline { 3 - 6 } & & No. 1 & No. 2 & No. 3 & No. 4 \\
\hline Mass fraction of soluble solids, \%, not less & 40 & 42 & 42 & 43 & 43 \\
Mass fraction of titratable acidity, \% & $0.5-2.5$ & 0.3 & 0.3 & 0.4 & 0.4 \\
Mass fraction of mineral impurities, \%, no more & 0.03 & 0.01 & 0.01 & 0.01 & 0.01 \\
\hline
\end{tabular}

plum mixture component without any additives which are aluminium and silicium. However, second, third and fourth samples did not have these elements. Probably, this disappearance is interconnected with the growing of total macroelements content.

Table 4. Content of chemical elements in the plum fillings

\begin{tabular}{ccccc}
\hline $\begin{array}{c}\text { Name of } \\
\text { element }\end{array}$ & \multicolumn{4}{c}{ Samples, mass, in mg/kg } \\
\hline carbon & 25.88 & 19.9 & 22.64 & 18.64 \\
oxygen & 42.65 & 41.2 & 41.79 & 42.63 \\
sodium & 0.33 & 0.06 & 0.12 & 0.15 \\
magnesium & 0.93 & 1.09 & 1.03 & 1.4 \\
aluminium & 0.73 & 0 & 0 & 0 \\
silicon & 0.32 & 0.07 & 0 & 0 \\
phosphorus & 1.87 & 2.34 & 2.26 & 2.35 \\
sulphur & 0.46 & 0.46 & 0.41 & 0.6 \\
potassium & 24.99 & 32.32 & 29.5 & 31.08 \\
calcium & 1.69 & 2.38 & 1.81 & 2.76 \\
iron & 0.16 & 0.19 & 0.44 & 0.16 \\
\hline
\end{tabular}

Thus, the presented samples have high nutritional values and essential macro- and microelements: sodium, magnesium, phosphorus, sulphur, potassium, calcium, iron and other.

\section{Conclusion}

It was determined, that the organoleptic characteristics and the physicochemical indicators of all plum fillings fully met the requirements of GOST 32741-2014. As a result of the «Just-About-Right-Test» more than $80-90 \%$ of the questioned respondents selected the plum filling with gelatin and lemon. The content of mineral substances in the plum fillings was determined by the method of Mass-spectrometry with inductively coupled plasma (ICP-MS) and using a Scanning Electron Microscope (SEM). The presented samples have high nutritional values and essential macro- and microelements: sodium, magnesium, phosphorus, sulphur, potassium, calcium, iron and other. Proposed plum filling has wide range applications, as inside and outside for the covering of confectionery, thereby organoleptic properties and nutritional value of final product could be enriched. 
A)
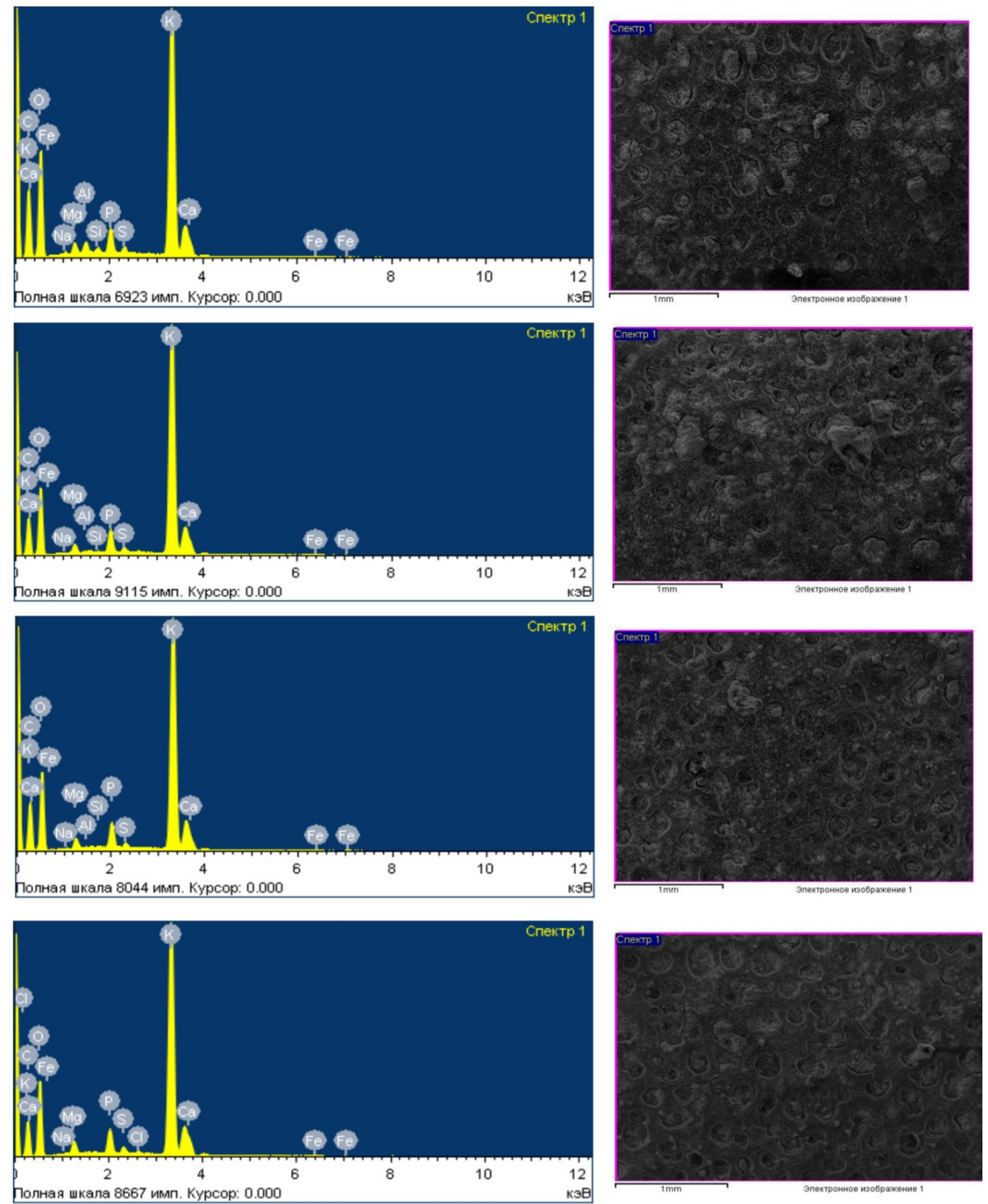

Figure 1. ICP-MS of samples A) No. 1; B) No. 2; C) No. 3; D) No. 4.

\section{References}

Alexeeva, N.V., Urazbayeva, K.A., Orymbetova, G.E., Alibekov, R.S. and Mamaeva, L.A. (2018). Influence of quince powder on the properties wheat bread. News of Kazakhstan Science Scientific and Technical Journal, 3(137), 175-190.

Alibekov, R.S, Gabrilyants, E.A, Tursunbay, L.M. and Konakbay, A.G. (2019). Antioxidant properties and nutritional value of plum presented at the International conference of Industrial Technologies and Engineering - ICITE-2019, p. 168-172. Shymkent, Kazakhstan: M.Auezov' SKSU.

Alibekov, R.S. and Utebaeva, A.A. (2014). Physicochemical research of macro-and microelements composition of tomato juice with various additives. Bulletin of Karaganda University, Series Chemistry, 4(76), 24-33.

Alibekov, R.S., Gabrilyants, E.A., Alibekova Z.I. and Norov, Zh.Sh. (2018). Antioxidants of natural origin. Proceedings of $\mathrm{V}$ International scientific practical conference Industrial Technologies and Engineering
2018, p. 144-147. Shymkent, Kazakhstan: M.Auezov' SKSU.

Alibekov, R.S., Kaiypova A.B., Urazbayeva K.A., Ortayev A.E. and Azimov A.M. (2019). Effect of substitution of sugar by high fructose corn syrup of the confiture on the base of Physalis. Periodico Tche Quimica, 16(32), 688-697.

Alibekov, R.S., Sikorski, M., Urazbayeva, K.A. and Gabrilyants, E.A. (2017). Physico-chemical study of macro-and microelement composition of the enriched macaroni products. News of the National Academy of Sciences of the Republic of Kazakhstan, Series Chemistry and Technology, 3, 13-20.

Alibekov, R.S., Utebayeva, A.A., Kaldybekova, A.Zh., Gabrilyants, E.A. and Balabekova, A.S. (2016). Sensory analysis of eastern sweet - parvarda. Industrial Technology and Engineering, 2(19), 5-15.

Alimova, M.A., Musulmanova, M.M., Urazbayeva, K.A., Alibekov, R.S., Usenova, S.O. and Abzalov, R.F. (2014). Standardization of fruit and vegetable raw materials in a multi-component functional filling 
for caramel. Herald of Kazan Technological University, 17(14), 411-413.

Arifin, N., Siti Nur Izyan, M.A. and Huda-Faujan, N. (2019). Physical properties and consumer acceptability of basic muffin made from pumpkin puree as butter replacer. Food Research, 3(6), 840 845. https://doi.org/10.26656/fr.2017.3(6).090

Benmeziane, F., Djermoune - Arkoub, L., Boudraa, A.T. and Bellaagoune, S. (2018). Physicochemical characteristics and phytochemical content of jam made from melon (Cucumis melon). International Food Research Journal, 25(1), 133 -141.

Clausen, M.V., Hilbers, F. and Poulsen, H. (2017). The Structure and Function of the Na,K-ATPase Isoforms in Health and Disease. Frontiers in Physiology, 8, 371. https://doi.org/10.3389/ fphys.2017.00371

Davidson, A. and Jaine, T. (Eds.) (2014). The Oxford Companion to Food, p. 213. United Kingdoms: Oxford University Press. https://doi.org/10.1093/ acref/9780199677337.001.0001

Ertekina, C., Gozlekcib, S., Kabasa, O., Sonmezc, S. and Akinci I., (2006). Some physical, pomological and nutritional properties of two plum (Prunus domestica L.) cultivars. Journal of Food Engineering, 75(4), 508-514.

j.jfoodeng.2005.04.034

Federal Agency for Technical Regulation and Metrology. (2015). Fresh plum for industrial processing (GOST 21920-2015). Retrieved from: http://docs.cntd.ru/document/1200127432

Federal Agency for Technical Regulation and Metrology. (2015). White sugar (GOST 332222015). Retrieved from: http://docs.cntd.ru/ document/1200123909

Federal Agency for Technical Regulation and Metrology. (2016) Semifinished products. Fruit and vegetable fillings and podvarki (GOST 32741-2014) Retrieved from: http://docs.cntd.ru/ document/1200111758

Federal Agency for Technical Regulation and Metrology. (2017). Citrus fruits (GOST 343072017). Retrieved from: http://docs.cntd.ru/ document/1200157849

Gurak, P.D., Spada, J.C., Campos, H.G. and Marczak, L.D.F. (2018). Improvement of phytochemicals compounds content in mango jelly with the incorporation of co-products generated in the pulp processing. International Food Research Journal, 25 (2), 814-819.

Ho, L.-H., Irisha Yasmira, S.R.R. and Norlia, M. (2020). Proximate composition, physicochemical characteristics and sensory evaluation of reducedcalorie belimbi fruit (Averrhoa belimbi) jam with maltito. Food Research, 4(5), 1545 - 1553. https:// doi.org/10.26656/fr.2017.4(5).090

Hosseini Ghaboos, S.H., Seyedain Ardabili, S.M. and Kashaninejad, M. (2018). Physico-chemical, textural and sensory evaluation of sponge cake supplemented with pumpkin flour. International Food Research Journal, 25(2), 854-860.

International Food Information Service. (2009). IFIS Dictionary of Food Science and Technology. 2nd ed., p. 106. Chichester, U.K.: Wiley-Blackwell.

Kassymova, M.K., Mamayeva, L.A. and Alibekov, R.S. (2012). Enrichment of marmalade by functional food ingredients. Journal of Industrial Technology and Engineering, 4(5), 46-49.

Maimanah-Faizah, I., Ismail-Fitry, M.R., Umi Hartina, M.R. and Rozzamri, A. (2020). Physicochemical and sensory properties of traditional baked cake (kuih bakar) with coconut milk and soy milk. Food Research, 4(5), 1435 - 1443. https:// doi.org/10.26656/fr.2017.4(5).068

Miller, R. (2016). Biscuits, Cookies and Crackers: Nature of the Products. In Caballero, B., Finglas, P.M. and Toldra, F. (Eds.) Encyclopedia of Food and Health, p. 445-450. USA: Academic Press. https:// doi.org/10.1016/B978-0-12-384947-2.00075-1

Peri, C. (2006). The universe of food quality. Food Quality and Preference, 17(1-2), 3-8. https:// doi.org/10.1016/j.foodqual.2005.03.002

Popel, S., Cropotova, J., Parshakova, L., Draganova, E., Pirgari, E., Kolesnichenko A., Pujailo E. and Zyryanova, E. (2018). Optimization of the composition of fillings with heat-stable properties presented at the Proceedings of International Conference Modern technologies, in the food Industry, p. 165-170. Chişinău, Moldova.

Satayev, M.I., Alibekov, R.S., Satayeva, L.M., Baiysbay, O.P. and Mutaliyeva, B.Z. (2015). Characteristics of activated carbons prepared from apricot kernel shells by mechanical, chemical and thermal activations. Modern Applied Science, 9(6), 104-119. https:// doi.org/10.5539/mas.v9n6p104

Shingisov, A.U., Alibekov, R.S., Myrkalykov, B.S., Musayeva, S.A., Urazbayeva, K.A. and Iskakova, S.K. (2016). Physicochemical Characteristics of the New Polyphyto-Component Composition for Food Industry. Biosciences Biotechnology Research Asia, 13(2), 879-886. https://doi.org/10.13005/bbra/2110

Shingisov, A.U. and Alibekov, R.S. (2017). Analysis of the moisture evaporation process during vacuum freeze-drying of koumiss and shubat. Heat and Mass 
Transfer, 53(5), 1571-1578. https://doi.org/10.1007/ s00231-016-1920-4

State Agroindustrial Committee. (1989). Gelatin (GOST 11293-89). Retrieved from: http://docs.cntd.ru/ document/1200023164

Thompson, M.M. and Wolsh, D.N. (1988). Guideline for spectrometric analysis with inductive-bonded plasma, p. 288. Moscow: Nedra.

Tkachenko, A. (2016). Consumer properties improvement of sugar cookies with fillings with nontraditional raw materials with high biological value. Eastern-European Journal of Enterprise Technologies, 3, 54-60. https:// doi.org/10.15587/1729-4061.2016.70950

Walkowiak-Tomczak, D., Reguła, J. and Łysiak, G. (2008). Physico-chemical properties and antioxidant activity of selected plum cultivars fruit. Acta Scientiarum Polonorum Technologia Alimentaria, 7 (4), 15-22. 